\title{
RECORDS OF HYMENOPTEROUS PARASITES IN PENNSYLVANIA
}

\author{
By A. B. Champlain.
}

Bureau of Plant Industry, Harrisburg, Pa.

Definite breeding records of Hymenopterous parasites are a ways valuable contributions to our knowledge of this order of insects. The following collection of fragmentary records of parasitic Hymenoptera and their hosts are from rearings by the author, and from notes in the file of the Bureau of Plant Industry, extending over a period of years. Due credit for the records obtained appears throughout the paper.

The recorded species which are in the collection of the Pennsylvania Bureau of Plant Industry were all identified or verified by leading authorities on Hymenoptera,-S. A. Rohwer and R. A. Cushman of the U. S. National Museum, and some by H. L. Viereck of the U. S. Bureau of Biological Survey. The abbreviations-Det. Roh., Det. Cush., Det. Vier.--designate the species identified by each.

\section{Evaniidwe}

Hemistephanus sp. (Det. Cush.). Hummelstown, Pa., Rockville, Pa., Magnolia, Md., is a parasite of Dicerca divaricata in Betula lenta and of unknown borers in Quercus bicolor and Quercus sp. Notes by H. B. Kirk and J. N. Knull.

Oleisoprister abbotii Westw., Hummelstown, Pa., reared from Liriodendron tulipifera infested by Leptura mutabilis.

Odontaulacus bilobatus (Prov.), (Det. Roh.) Mt. Holly, Pa., June 14, 1921-Knull and Champlain. Adults were flying around and alighting on dying hemlock Tsuga canadensis. Upon cutting into the bark a heavy infestation of Melanophila fulvoguttata was found in adult and pupal stages. In some cells adults and pupæ (one to a cell) of $O$. bilobatus were found with remnants of the host. 
Odontaulacus rugitarsis Cress. (Det. Cush.) New Bloomfield, Pa., June 16. Adults were plentiful flying around and alighting on cut white pine (Pinus strobus) infested by Scolytoids and Cerambycids.

Pammegischia burquei Prov. (Det. Cush.), Harrisburg, Pa. A parasite of Xiphidria champlaini Roh. in dead branches of Carpinus caroliniana; $X$. attenuata Nort. in dead branches of Tilia americana and of $X$. maculata in dead Acer rubrum. Adults fly during May.

\section{Braconido}

Macrocentrus delicatus Cress. (Det. Vier.). Willow Street, Pa. Reared from pupæ of Mineola indiginella.

Helconidea ligator Say (Det. Cush.), Hummelstown, Pa., Jan. 23. Reared from oak (Quercus bicolor) infested by Purpuricenus axilaris. J. N. Knull; West Chester, Pa. Reared from dead Morus sp. infested by borers, Camp Hill, Pa., from dead Robinia pseudacacia, infested by Neoclytus erythrocephalus, F. M. Trimble.

Helconidea borealis Cress. (Det. Roh.), Harrisburg, Pa. Parasite on Cerambycid larva in dead Rhus toxicodendron, H. B. Kirk, Hummelstown, Pa. Parasite of Cerambycid larvæ in dead mulberry (Morus rubra) branches,-J. N. Knull.

Helcon pedalis Cress. (Det. Roh.), Hummelstown, Pa. Parasite on Xylotrechus larvæ in dead hemlock (Tsuga canadensis), -J. N. Knull.

\section{Ichneumonidoe}

Nemeritis canescens (Grav.) (Det. Cush.), Butler, Pa., IX. 25. In flour mills. A parasite of Mediterranean flour moth.

Orthopelma luteolata (Grav.) (Det. Cush.), Chester, Pa. VI-27. Reared from Cynip galls on wild rose. 
Cremastus gracilipes Cush. (Det. Cush.), Rockville, Pa. Reared from cat tail rush infested by Dicymolomia julianalis; Collins, Pa. Lepidopterous larvæ infesting "cat-tails" growing along canal, caged IX-22, indoors-Nov. 23 to next April, many moths and ichneumonid parasites emerged-A. F. Satterthwait." Identified same as above.

Labena apicalis Cress. (Det. Cush.), Rockville, Pa. Parasite of Stenosphenus notatus in Hicoria sp., I-II,-J. N. Knull.

Xorides calidus (Prov.) (Det. Roh.), Harrisburg, Pa. Parasite of Phloeotrya 4-maculata in dead sumac (Rhus typhina).

Odontomerus canadensis Prov. (Det. Cush.), Hummelstown, Pa., V-18. Parasite of Cerambycid in sumac (Rhus sp.), Knull.

Glypta simplicipes Cress. (Det. Cush.), Philadelphia, Pa., V-20. Reared from larva of leaf tyer on Azalea sp.,J. K. Primm.

Scambus (Epiurus) tecumseh Vier. (Det. Cush.). Host-Dicymolomia julianalis Walsh, in cat-tail rush, Rockville, Pa., VI-6 to 19.

Tromatobia rufopectus Cress. (Det. Cush.). "Harrisburg, Pa., collected egg mass of garden spider from shrub. On opening egg cocoon found that eggs had been parasitized by an Ichneumonid, and the case contained a dozen or more whitish cocoons matted together. Upon opening one of these cocoons found the parasite in mature larval stage. Material caged. March 22 the parasites had emerged. There were twelve females and one male,J. R. Stear."

Scambus indigator Walsh (Det. Vier.), Willow Street, Pa. Reared from pupa of Mineola indiginella Zell.

Perithous pleuralis Cress. (Det. Cush.), Hummelstown, Pa. Cocoons found in old (borer?) burrows in Platanus occidentalis, II-17-Knull.

Ephialtes aequalis (Prov.) (Det.Cush), Ledy, Pa., from Codling moth puparia. 
Ichneumon irritator Fab., New Cumberland, Pa. Host-Cyllene pictus. Hummelstown, Pa., parasite of Chrybothris sp. larvæ found in sapwood of dead Cercis canadensis,-Kirk and Knull.

Ichneumon comstocki Cress. (Det. Vier.), Rockville, Pa. Reared from Evetria comstockiana,-V. A. E. Dæcke.

Rhyssa lineolata Kirby (Det. Cush.), Mt. Holly, Pa., June 14. Adult female ovipositing in dead hemlock infested by Urocerus albicornis.

Urocerus albicornis Fab., New Bloomfield, Pa. This horntail infested hemlock stumps, trees cut one year ago. At this time (Aug. 1) adult females are flying. Cutting into infested stumps we found pupæ of males and females, also mature larvæ, small larvæ and apparently newly hatched larvæ, as well as parasites.

Among the parasites, $R$. lineolata was common. Adults were collected from July 10 to 30 at various localities. On Aug. 1, at New Bloomfield, pupæ and newly transformed adults were chopped from the Urocerus cells. Observation by Knull and Champlain.

Rhysella humida Say (Det. Cush.), Rockville, Pa. A parasite of Xiphidria champlaini Roh. in dead Carpinus caroliniana.

Megarhyssa nortoni (Cress.), New Bloomfield, Pa., July 21 and August 1. Adults ovipositing in stumps infested by Urocerus albicornis,-Knull and Champlain.

Arotes formosus (Cress.) (Det. Cush.), Dauphin, Pa., Clarks Valley, VI-5. Parasite of Bellamira scalaris in dead river birch (Betula nigra),-Kirk and Champlain.

Gelis bruesi (Strickl.) (Det. Cush.), Rockville, Pa. Parasite on the eggs of Drassid spider. The spider egg cases were collected from the under side of stones. The cocoon of the parasite was in the space originally occupied by the spider egg mass. 
Gelis obscurus (Cress.) (Det. Cush.), Rockville, Pa. Parasite on the eggs of Drassid spider. Both winged and wingless forms were reared.

Acroricnus junceus Cress. (Det. Vier.), Conewago, Pa., V-7. Reared from nest of solitary wasp on Juniperus. Also reared from nest of Odynerus tigris,-V. A. E. Daecke.

Itamoplex vinctus (Say). (Det. Cush.), Chambersburg, Pa., Reared from cocoons of peach tree borer (Synanthedon exitosa),-E. M. Craighead.

Agrothereutes nuncius Say (Det. Vier.), Harrisburg, Pa. Very common parasites in the cocoons of Callosamia promethea.

Lagarotis diprioni Roh. (Det. Cush.), Wyomissing, Pa. Reared from the cocoons of Diprion lecontei.

Chromocryptus nebraskensis Ashm. (Det. Cush.), Obelisk, Pa., XI-18. Reared IV-21, from the cocoon of Tolype velleda.

Amblyteles. Many species of this genus overwinter in the adult stage in cracks in bark, in old borer cells in logs and beneath stones. During the winter months they may be found packed closely together in cells in logs, six to a dozen specimens, sometimes one species, often a number of species together. Many of the records show that they are primary parasites of Lepidoptera, and usually emerge after the host has entered the pupal stage.

Amblyteles malacus Say (Det. Cush.), Harrisburg, Pa. Emerged IV-18 from Arctiid pupa from beneath bark in old willow log. Linglestown, Rockville, Harrisburg, Pa. Reared from Arctiid pupæ,-Kirk and Champlain.

Amblyteles cincticornis (Cress.) (Det. Vier.), Enid, Pa. Reared from moth pupa on cabbage. Adults collected in hibernation.

Amblyteles subcyaneus Cress. (Det. Vier.), Harrisburg, Pa. Reared from Arctiid pupæ from under bark of willow $\log ,-$ A. F. Satterthwait \& W. S. Fisher. 
Amblyteles extrematatis (Cress.) (Det. Vier.). (Det. Cush.), Penbrook, Pa. Reared from pupa of Arctiid (Gaberasa ambigualis), D. K. McMillan. Also reared from Arctiid pupæ from other localities in Pennsylvania.

Amblyteles unifasciatorius (Say) (Det. Cush.), Harrisburg, Pa. Reared from Lepidopterous pupa.

Amblyteles paratus Say (Det. Cush.), Linglestown, Pa. Reared from small moth pupa,-Kirk and Champlain.

Amblyteles rufiventris Brullé (Det. Cush). From pupa of Vanessa huntera,-D. K. McMillan \& W. S. Fisher.

(Det. Vier.). Emerged from pupa of Vanessa cardui,P. R. Myers.

Amblyteles duplicatus Say (Det. Cush.), Enola, Pa. Reared from pupæ of Eudamus tityrus,-Kirk and Champlain.

Amblyteles coeruleus Cress. (Det. Cush.), Harrisburg, Pa. Reared from moth pupa,-Kirk and Knull.

Amblyteles sp. near signatipes (Cress.) (Det. Cush.). Reared from moth pupa collected beneath bark, Harrisburg, Pa., II-24,-P. R. Myers.

\section{Vanhorniidoe}

Vanhornia eucnemidarum Cwfd. Parasite of Tharops ruficornis in dead maple, Hummelstown, Pa.,-Knull and Champlain.

\section{Ibaliidoe}

Ibalia ensiger Norton, (Verified Roh.) New Bloomfield, Pa., -VIII. Ovipositing in hemlock, August 1, pupæ and adults from cells of Urocerus albicornis in stumps of hemlock,-Knull and Champlain.

Ibalia maculipennis Haldeman. (Det. Champlain). Very common in the vicinity of Harrisburg where it is a parasite of Tremex columba in hickory. 

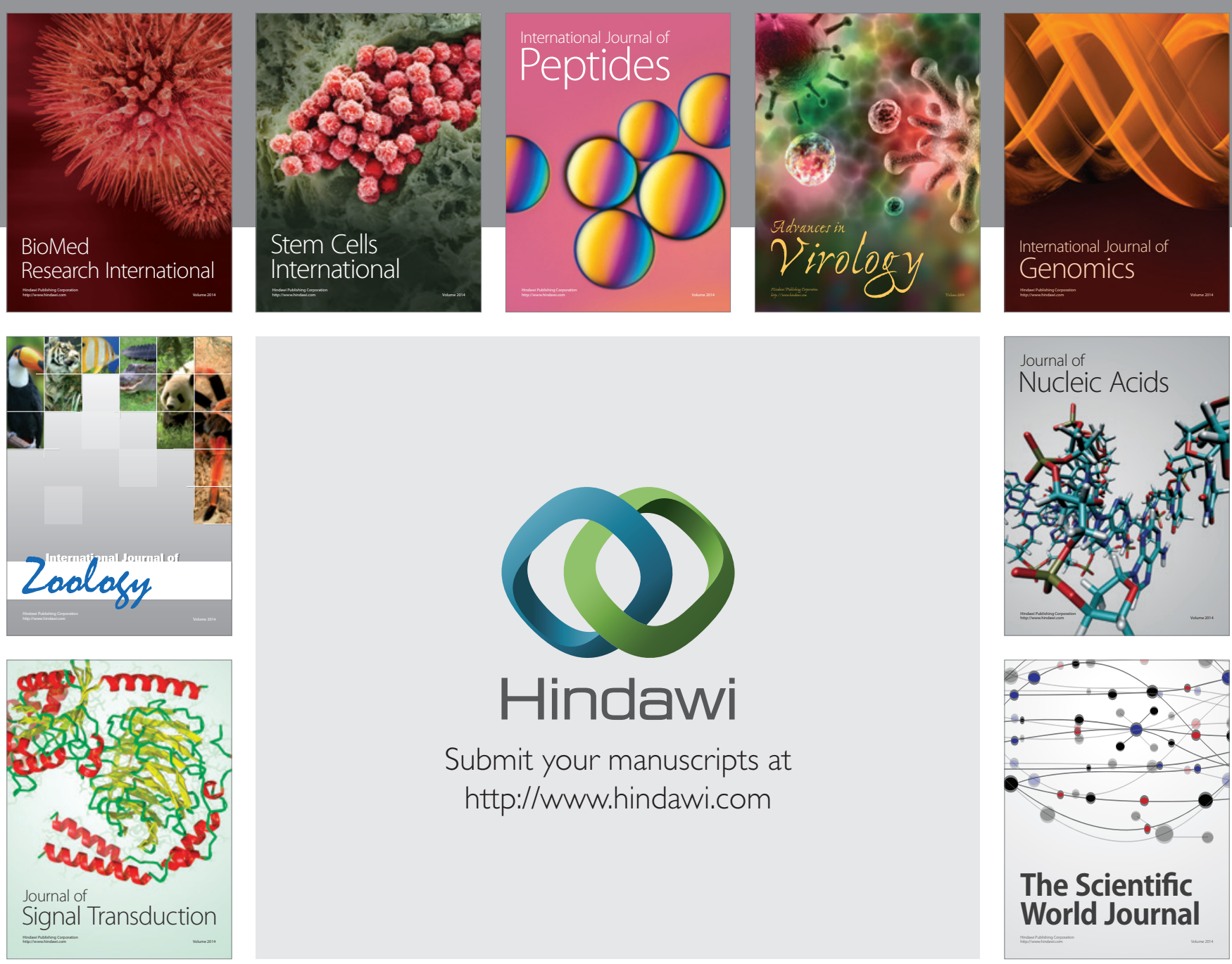

Submit your manuscripts at

http://www.hindawi.com
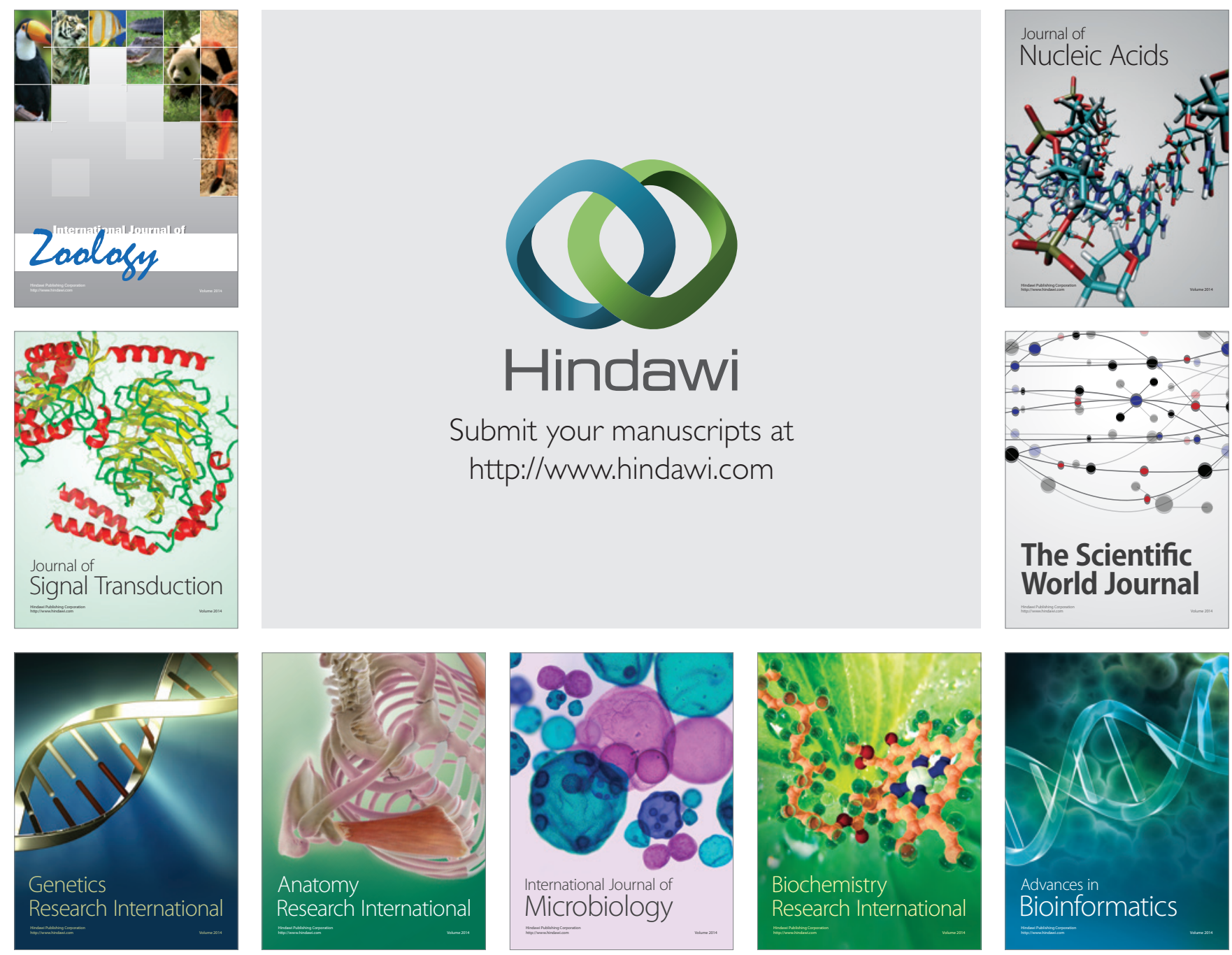

The Scientific World Journal
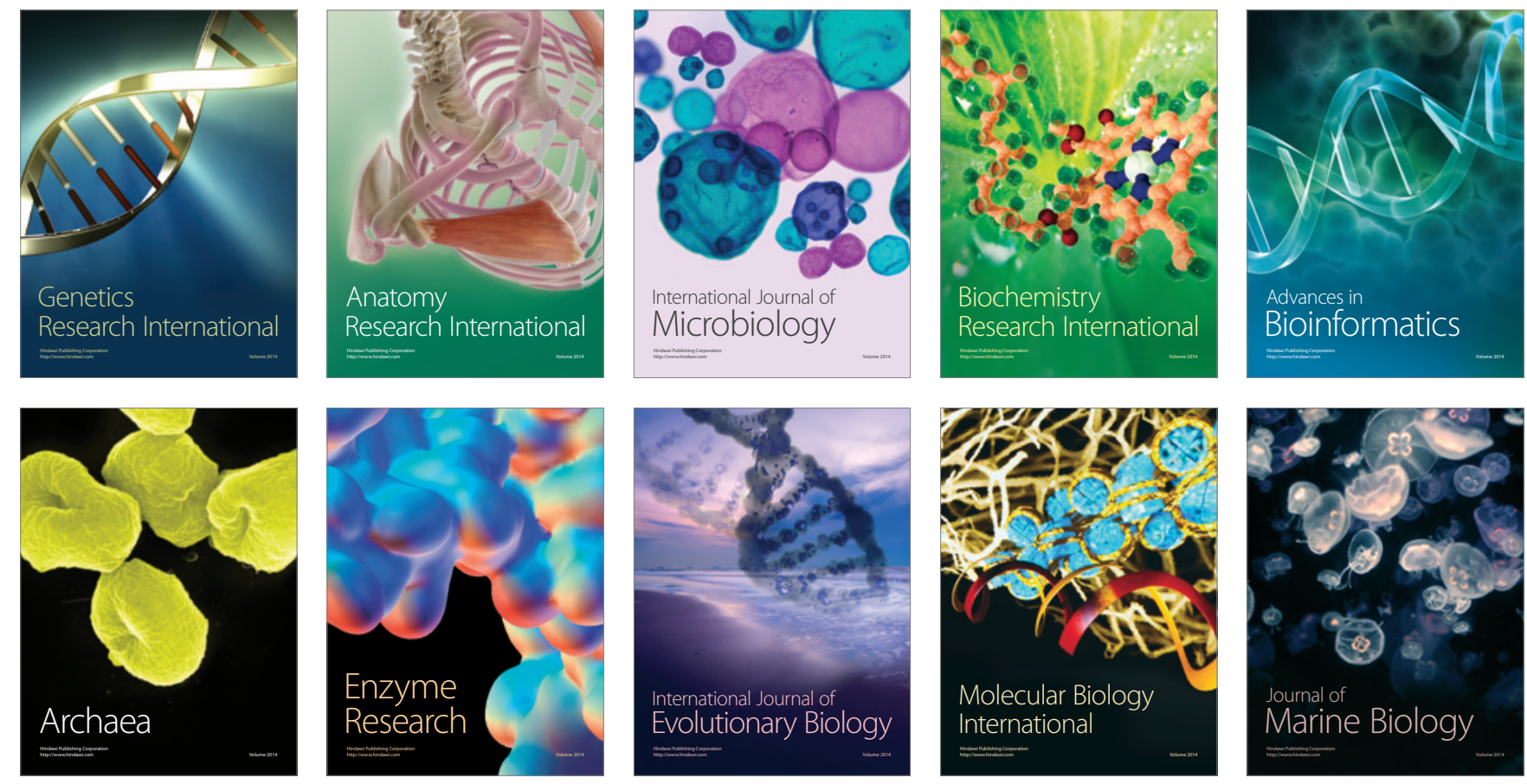